\title{
CONSEPTUAL CONTENT OF INFRASTRUCTURAL SUPPORT FOR THE DEVELOPMENT OF POST-CONFLICT TERRITORIES OF LUHANSK REGION IN THE WAR CONFLICT AND PANDEMIC CONDITIONS
}

\author{
Ustymenko V.1, Pashyna N. ${ }^{2}$, Sieriebriak K. ${ }^{3}$, Hrechana S.4*, Zablodska D. ${ }^{4}$ \\ ${ }^{1}$ State Institution V.K. Mamutov Institute of Economic and Legal Research of the National Academy of Sciences of Ukraine \\ ${ }^{2}$ Department of International Relations and Foreign Policy, Mariupol State University
}

${ }^{3}$ Department of economics and entrepreneurship, East Ukrainian National University named after V. Dahl

${ }^{4}$ State Institution V.K. Mamutov Institute of Economic and Legal Research of the National Academy of Sciences of Ukraine" *Corresponding author. E-mail: super.nauka2021@ukr.net

Received 2201 2021; Accepted 01032021

\begin{abstract}
The article examines, identifies and studies the key types of infrastructure (industrial, housing and communal, social, transport, agricultural and energy) and their state for the territories` development of Luhansk region, which controlled by the Government of Ukraine, in order to create appropriate conditions for effective management of its development and counteract the negative impact of the pandemic. The article uses methods of comprehensive and auxiliary factor method, analysis and synthesis, statistical, comparative analysis, modelling, which made it possible to research the significant problems and opportunities for the infrastructural regional support. The main results of scientific research reveal on substantiate conceptual provisions of the infrastructural support for the post-conflict territories development to identify problematic hot spots in the state of the infrastructure that hinder the sustainable development of the Luhansk region, which made it possible to reveal unsatisfactory results of the state of infrastructure subsystems in the region. It proposes to adjust the strategic and operational purposes of the long-time regional development and focus on housing and social infrastructure facilities. For solve identifying problems it offers to form and implement the Concept provisions for the socio-economic development of post-conflict territories, especially the Luhansk region in the conditions of war conflict and COVID-19 pandemic.
\end{abstract}

Keywords: development, indicators, infrastructure, Luhansk region, pandemic, post-conflict territories, war conflict, Ukraine.

JEL Codes: H54; O18; O30.

\section{Introduction}

In recent years, the issues of increasing the territories`competitiveness not only at the national but also at the local level have become increasingly important. Such innovations intensify localization trends every year, encouraging local areas to pay more attention to the development of infrastructure. This issue is especially acute for the eastern regions of Ukraine, in particular Donetsk and Luhansk regions, which have been suffering from hostilities since 2014. In such conditions, regions should not only achieve operational goals within their development strategies, but also consider the whole process of strategic planning of the territory through the prism of competitiveness. This problem can solve by concentrating maximum attention on the development of critical infrastructure facilities, as the further development of the Luhansk region depends on its restoration.

During the seven years of conflict, the region has transformed from an economically developed region with a large industrial and transport infrastructure to a depressed postconflict area, which is not only lag behind in socio-economic development but also suffers

Copyright (C) 2021 Author(s), published by Vytautas Magnus University. This is an open access article distributed under the terms of the Creative Commons Attribution Non-Commercial 4.0 (CC BY-NC 4.0) license, which permits unrestricted use, distribution, and reproduction in any medium provided the original author and source are credited. The material cannot be used for commercial purposes. 
from weak infrastructure, especially in the social sphere. Simultaneous action of such negative factors requires scientific and analytical research on the problems of infrastructural support of development of the post-conflict territories of eastern Ukraine. Its results could help reduce critical tensions between stakeholders in the development of the Luhansk region, build the infrastructure of post-conflict areas and help increase the level of competitiveness of such areas and the country as a whole. The above emphasizes the relevance of this scientific problematic of the article as well as proves the relevance in today's competitive environment of such an imperative of regional development as the need for infrastructure, taking into account the adoption of sound management decisions.

The post-conflict areas refer to the regions where active hostilities have recently ended in an international armed conflict, or areas where no direct combat operations have taken place. Nevertheless, they are close to the line of contact between the parties to the ongoing conflict and the vital activity of such territories is quite sensitive to its course. However, Luhansk region, which currently suffers from the spread of COVID-19 coronavirus disease, has the greatest negative impact on socio-economic development due to infrastructural losses.

Preliminary research on detection and resolution bottlenecks in the infrastructure of regional areas do not contain any analysis in the context of identifying such problems in post-conflict areas. In addition, trends and problems of infrastructure development in the regions are constantly changing under the influence of transformational processes, especially due to hostilities and the global pandemic. This situation requires further research to study the trends of infrastructural support of post-conflict areas that determines the purpose of research.

It is well known that infrastructure plays a key role in the development of the economy, as its existence is associated with the state of productive forces and the territorial division of labour, as well as the efficiency of material production. Infrastructure development depends on the specifics of industries in the regions and the structure of production in modern conditions characterize by a growing focus on the regional economic system. In this connection, a pool of foreign and domestic scientists studied the issues of theoretical and methodical architecture of infrastructural support, among them Amr, S. (Amr, 2013), Budić, Z. (Budić, 1994), Albalate, D., Bel, G. (Albalate \& Bel \& Fageda, 2012), Lytvynchuk, I., Skydan, O., Ivaniuk, O. (Lytvynchuk \& Skydan, \& Ivaniuk, 2021).

The infrastructural support problem of local governance and territorial development highlighted in the scientific works of such foreign economists as Fageda, X., Olivieri, C. (Fageda \& Olivieri, 2019), Eyitope, O. (Eyitope, 2020), Chen, Zh., Haynes, K. (Chen $\&$ Haynes, 2018). The scientific works of economists contain fragmentary studies on the features of infrastructural support for the development of post-conflict territories and obtaining the possible effect of the successful implementation of such support. However, for post-conflict areas, infrastructural provision of their development provides a broader perspective on its essence (Rohozian \& Noskova, 2017). Unfortunately, infrastructure is the first group of facilities to be destroy during and because of war or armed conflict. Therefore, its restoration is a strategy of reconciliation, assuming that improving ties can increase the competitiveness of trade and change people's relationships with each other (Zablodska \& Hrechana \& Zablodska, 2020). Although infrastructure has always existed in post-conflict reconstruction, today it mobilizes during long-term conflicts, investing in the desire to improve security and stability.

The work bases on the generalization of primary statistical information on the development of the region, as well as data from the official websites of local governments. However, due to the incompleteness of the decentralization reform and the associated change in the statistical observation system, much of the secondary analytical data provide using official government reports, analytical and expert studies, and electronic periodicals with a sufficient level of reliability. 
It is advisable to combine the methodological elements of structural-oriented and process analysis, which will allow to correlate the dialectic of infrastructure and infrastructure in the whole set of socioeconomic relations of the region. The basis of methodology to achieve this goal chose comprehensive analysis, which allows assessing all types of infrastructure: housing and communal, social, industrial, energy, agricultural, transport. The auxiliary factor method allows singling out the impact on the sustainable development of the region of the international armed conflict between Ukraine and the Russian Federation, as well as the coronavirus COVID-19 pandemic. In addition, the article uses methods of analysis and synthesis, statistical, comparative analysis, modelling, which help to research significant problems and opportunities for the infrastructure supporting for the regional development.

The purpose of the article is to reveal and substantiate conceptual content of the infrastructural support for the post-conflict territories development to ensure key areas for further strategic development of the Luhansk region.

To achieve this purpose it proposes to solve the following tasks:

- analyze and justify the main types of infrastructure that provide development of post-conflict areas;

- identify problematic hot spots in the state of the infrastructure that hinder the sustainable development of the Luhansk region, which made it possible to reveal unsatisfactory results of the state of infrastructure subsystems in the region;
- suggest solutions to identified problems in terms of war conflict and COVID19 pandemic.

\section{Results}

Providing development requires the efficient operation and development of all major types of infrastructure. For post-conflict areas, according to the experts (Jones \& Howarth, 2012), both production and social infrastructure are central, providing the basis for generating growth and disseminating the benefits of economic growth geographically and socially. However, the crucial criterion for selecting its priority species in the context of priority recovery is the type of infrastructure that significantly damaged by the conflict and whether such infrastructure is crucial to support the various activities (Anand, 2005).

Approbation area of the research presented by the Luhansk region, which is situated in the East of Ukraine and has a unique situation as of the current conditions of the coronavirus COVID-19 pandemic and military actions. According to the results of experimental research, the conceptual features of the infrastructural support of post-conflict territories analysed. Due to the extremely large pool of analytical information and indicators that made up the study, and in order to maintain a balance between the graphical and analytical article part, it is advisable to present the decomposition of infrastructure for postconflict areas (Fig. 1), without losing the importance and significance of empirical research. 


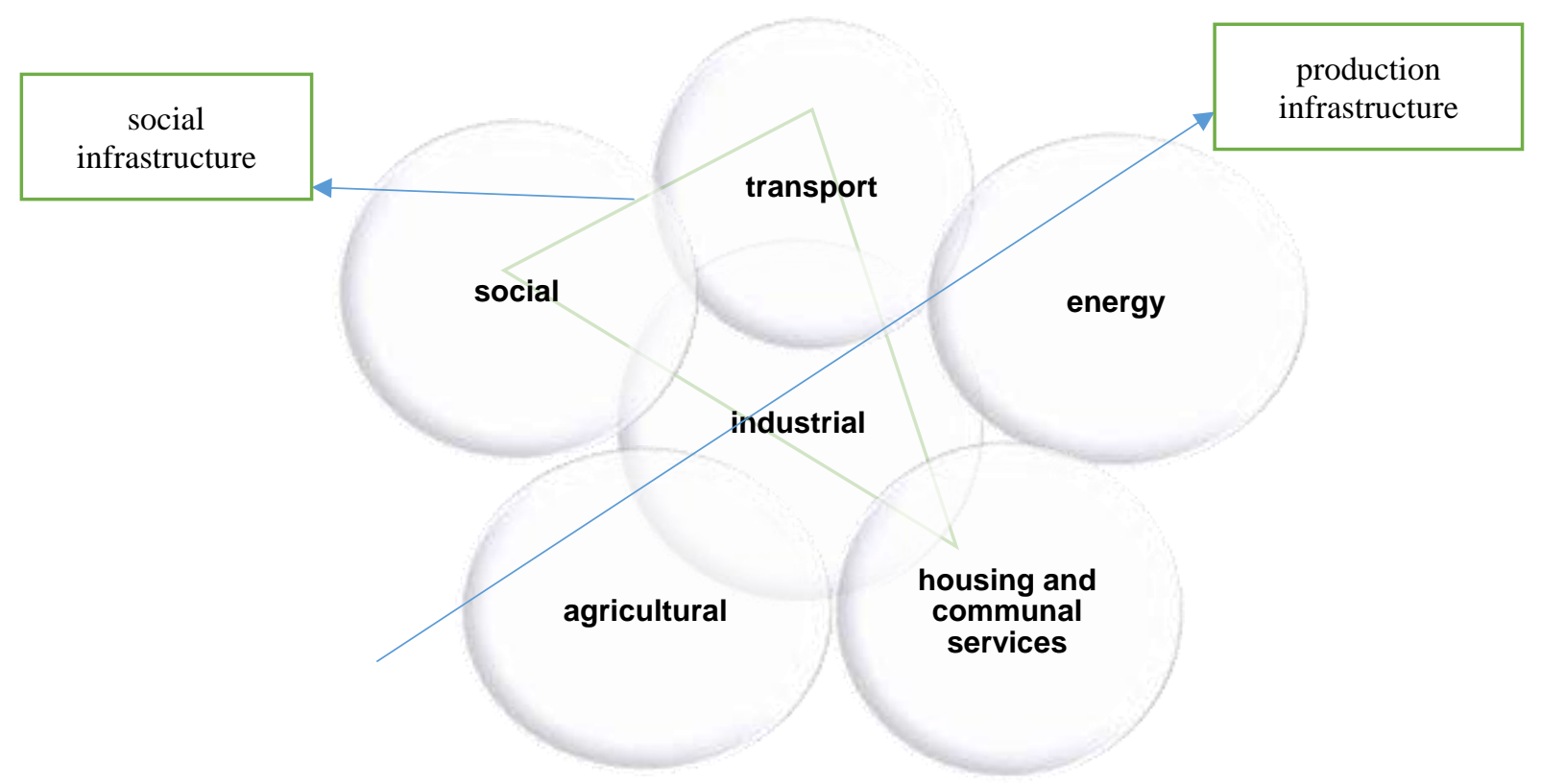

Figure 1. Decomposition of infrastructure supporting for the post-conflict areas development

Housing and communal infrastructure of Luhansk region has suffered significant damage. Because of hostilities, more than 50,000 homes on both sides of the demarcation line damaged. The housing stock of the region in both urban and rural areas in 2014 compared to 2013 decreased three times - from 55 million $\mathrm{m} 2$ of total area to 17.7 million $\mathrm{m} 2$ (Main Department of Statistics in Luhansk region, 2020a). Active hostilities in the region led to the destruction of a significant number of not only residential buildings but also nonresidential and engineering structures, as well as a critical decline in construction activity. The region has a negative situation in the field of housing construction, reconstruction and modernization of infrastructure, etc. New construction in the region is almost nonexistent. The main work in this direction aimed at repairing and repairing damaged objects.

Centralized water supply and sewerage of Luhansk region represented mainly in urban settlements. According to local governments, these networks are $50 \%$ obsolete and emergency, sewerage networks by $57 \%$, and the degree of wear in cities reaches $70 \%$, and in rural areas $29 \%$. The technical condition of almost all sewage treatment plants is unsatisfactory, 12 of them need major repairs. Of the 88 sewage-pumping stations, 50 are in need of major repairs $62.5 \%$ (Luhansk
Regional State Administration, 2020b). The situation with water supply complicated by the fact that one of the ten regional specialized water suppliers is carrying out a humanitarian mission, providing up to $90 \%$ of extracted water to the temporarily occupied territory. The problem is that the budget of the region does not provide funding for compensation of such costs, which leads to unprofitable operation of KP "Popasnyansky district water utility" and its possible shutdown.

A rather difficult situation has also developed with the operation of district heating systems, which used by $65 \%$ of the urban and $0.4 \%$ of the rural population of the region. It characterizes by emergency wear of heating networks by $42.4 \%$, moral and physical aging of boiler equipment, low level of automation and efficiency (70-85\%). This and the use of natural gas as the main type of fuel $(70 \%)$ leads to a high share of fuel in heat tariffs, increasing social tensions due to the need to increase them (Luhansk Regional State Administration, 2020b).

Social infrastructure has also suffered significant losses due to the armed conflict and the occupation of parts of the territories. Some of its spheres were divided (the sphere of education), and specialized medical care was practically lost. Unrestored sectorial infrastructure of the region damaged, 


\section{Management Theory and Studies for Rural Business and Infrastructure Development}

eISSN 2345-0355. 2021. Vol. 43. No. 1: 67-76

Article DOI: https://doi.org/10.15544/mts.2021.06

unfortunately, cannot provide adequate protection and development. As a result of the occupation of part of the region on the territory where the state authorities of Ukraine exercise their powers, the network of educational infrastructure has been significantly reduced (Table 1).

\section{Table 1. Indicators of educational infrastructure in Luhansk region for the period 2013-2019 (Main Department of Statistics in Luhansk region, 2020b)}

\begin{tabular}{|c|c|c|c|c|c|c|c|}
\hline Indicators & 2013 & 2014 & 2015 & 2016 & 2017 & 2018 & 2019 \\
\hline Number of preschool institutions, units & 598 & 259 & 237 & 248 & 253 & 250 & 250 \\
\hline Number of children, thousand people & 58,1 & 15,7 & 15,0 & 15,5 & 15,8 & 14,9 & 14,5 \\
\hline Number of general secondary education institutions, units & 690 & 315 & 308 & 300 & 293 & 280 & 276 \\
\hline Number of students, thousand people & 170,9 & 58,6 & 51,5 & 52,3 & 53,2 & 54,5 & 55,2 \\
\hline Number of vocational education institutions, one. & 78 & 28 & 26 & 24 & 24 & 23 & 22 \\
\hline Number of students, thousand people & 24,1 & 6,3 & 5,9 & 5,9 & 5,6 & 4,9 & 4,7 \\
\hline Number of free economic zones (colleges, technical schools), units & 26 & 10 & 8 & 8 & 8 & 8 & 8 \\
\hline Number of students, thousand people & 15,3 & 4,7 & 2,6 & 2,6 & 2,3 & 2,5 & 2,3 \\
\hline Number of free economic zones (universities, academies, etc.), units & 8 & 2 & 4 & 4 & 5 & 4 & 4 \\
\hline Number of students, thousand people & 66,3 & 17,6 & 17,2 & 15,7 & 16,8 & 18,4 & 17,8 \\
\hline
\end{tabular}

The system of higher education are suffering the biggest job losses, which from 2013 to the present has reduced the system of its institutions by $64.7 \%$ and is represented by 8 institutions of I-II levels of accreditation and 4 institutions of III-IV levels of accreditation. Due to the initiated programs to promote the process of distance learning and simplify the procedures for admission to higher education, including through the educational centres "Donbas is Ukraine", in 2019890 entrants graduates from the temporarily occupied territory of Luhansk region entered the institutions of higher education. Despite the fact that the number of students over the 20132019 period has sharply decreased and despite the presence of territorial differentiation, the average occupancy of general secondary education corresponds to the average in Ukraine, amounting to $44.8 \%$ and the number of students per 1 teacher is nine people.

In recent years, it was restoring the social infrastructure of Luhansk region, which suffered during the hostilities, as out of 179 social protection facilities (social protection department, territorial centres of social services (providing of social services). The region is developing a system of modern CNAPs, which have more than 20 branches in villages, territorial centres of social services for families, children and youth, territorial centres of social services / social services, Social Rehabilitation Centres, Employment Centres and employment agencies, etc.

Under COVID-19 pandemic, this state of medical infrastructure and services does not reduce the incidence. In the Luhansk Regional Children's Clinical Hospital in Lysychansk, there is a department where children with COVID-19 pandemic are treated. Also, in the Luhansk region, the institutions to which patients with COVID-19 pandemic are hospitalized have been identified: the Rubizhne Central City Hospital; KNP "Starobilsk District Territorial Medical Association"; KNP "Lysychansk Multidisciplinary Hospital", KNP "Bilovodsk Multidisciplinary Hospital"; KNP "Sievierodonetsk City Multidisciplinary Hospital". Medical institutions of the region supplied with oxygen by PJSC "Sievierodonetsk Association of Nitrogen".

Copyright (C) 2021 Author(s), published by Vytautas Magnus University. This is an open access article distributed under the terms of the Creative Commons Attribution Non-Commercial 4.0 (CC BY-NC 4.0) license, which permits unrestricted use, distribution, and reproduction in any medium provided the original author and source are credited. The material cannot be used for commercial purposes. 
The transport infrastructure of Luhansk region includes railway, road and electric transport, which developed mainly at the expense of state and communal enterprises. However, as the railways and transportation logistics were disrupted because of hostilities, the main burden of traffic fell on road transport. In turn, the region's road infrastructure and public transport were also severely damaged (80\% of the road surface was destroyed), especially along the demarcation line and in isolated areas, making it much more difficult to travel to urban centres and access basic services. The length of public roads of local significance is $2439.0 \mathrm{~km}$, of national importance $-1177 \mathrm{~km}$, more than 920 $\mathrm{km}$ of which need repair. State and regional funds for the construction of roads and bridges are catastrophically lacking, so the restoration of roads in 2012-2015 was not funded. Since 2016, the region has adopted a relevant regional program, which began the development of roads.

The bus route network of the region includes 170 suburban and 131 intercity (intraregional) public bus routes, which serve 19 passenger carriers, including 10 legal entities and 9 individual entrepreneurs. Every day, 239 buses run on the line, including 156 on suburban and 102 intercity bus routes. The most popular route (about 70 buses) is the checkpoint across the line of demarcation of the Stanytsia Luhanska checkpoint, but this is clearly not enough. The total length of trolleybus lines in the region is $73.4 \mathrm{~km}$, of which in Lysychansk - $18.9 \mathrm{~km}$, in Sievierodonetsk - 54.5 km (Luhansk Regional State Administration, 2020b).

The railway and automobile infrastructure of the region is in an extremely difficult condition, which creates problems with freight and passenger transportation, harms the development of the region's economy. Due to problems with logistics, Luhansk region annually loses 600-700 million UAH. Such preconditions did not contribute to the effective work of the industry during the spread of coronavirus COVID-19 pandemic, especially during the complete cessation of public and rail transport in March-May 2020.
The load on the only entry-exit checkpoint in the region in the temporarily occupied territory of Stanytsia Luhanska, which operated at high risk throughout the pandemic, is critical. In order to reduce the level of morbidity, the conditions of crossing the demarcation line were constantly changing and improving.

Agricultural infrastructure. The territory of Luhansk region covers 26.7 thousand $\mathrm{km}^{2}$. At the same time, the largest share of land $(73.3 \%)$ used in agricultural production - citizens, $24.4 \%$ - use $41.4 \%$ of land by agricultural enterprises. A significant part of the land belongs to the category of "disturbed lands" - those that have lost their useful properties and soil fertility due to the influence of natural and anthropogenic factors (Luhansk Regional State Administration, 2020b). The main consequences of 2014 for agriculture in the region are the complete or partial loss of production capacity of the processing industry, when all the leading enterprises remained in the territory not controlled by the Ukrainian authorities. As a result, Luhansk region transformed into an agrarian region. Today, its agro-industrial complex provides about $20 \%$ of gross value added and is one of the main budget-generating sectors of the economy.

Most of the agro-industrial formations (1,044 units) and 42.8 thousand personal farms carry out the production of agricultural products in the post-conflict area of the region. Almost 140 small and medium-sized enterprises in eight subsectors are engaged in processing of agricultural products in Luhansk region: baking, flour and cereals, oil and fat, meat, dairy, beer and non-alcoholic, feed, confectionery. To meet the needs of the population of the region, almost all types of food produced, except for sugar, alcohol, alcoholic beverages, canned food, fish and baby food. The food industry characterized by incomplete capacity utilization in the following industries: dairy industry - about $30 \%$, bakery $-50 \%$, oil production $-87 \%$ (Luhansk Regional State Administration, 2020).

Production of dairy products represented by four enterprises: PJSC "Bilovodsk MRZ", 


\title{
Sciendo
}

\author{
Management Theory and Studies for Rural Business and Infrastructure Development \\ eISSN 2345-0355. 2021. Vol. 43. No. 1: 67-76 \\ Article DOI: https://doi.org/10.15544/mts.2021.06
}

PE "Prodgrupservice”, PJSC "Starobilsk Dairy Plant", LLC "Markivka Cheese Factory", the production capacity of which is 135 thousand tons per year. The range of products is more than 90 items. LLC JV "Nibulon", "Kernel Trade", "Cargill", "Serna", PJSC "Agrarian Fund" and "Agroton" (Luhansk Regional State Administration, 2020b) carry out wholesale purchase of grain and industrial crops in the region.

Thus, the agricultural infrastructure is quite successful in ensuring the operation of the agro-industrial complex of the region, which became after 2014 one of the promising areas of development of the region. The industry also has a number of problems related to the international conflict and the ongoing fighting, namely the loss of major domestic markets and destroyed logistics, severed production ties between agricultural producers and processing enterprises.

The industrial infrastructure of Luhansk region before the beginning of the armed aggression of Russia provided a significant economic potential of the region, allowing it to enter the five strongest industrial and economic regions of Ukraine. The main industries were metallurgy, chemical industry, production of coke and refined products, coal industry, mechanical engineering. After 2014, a small share of such industries as the coal industry, production of building materials, food and light industry, etc. remained in the territory controlled by the Ukrainian authorities (Fig. 2).

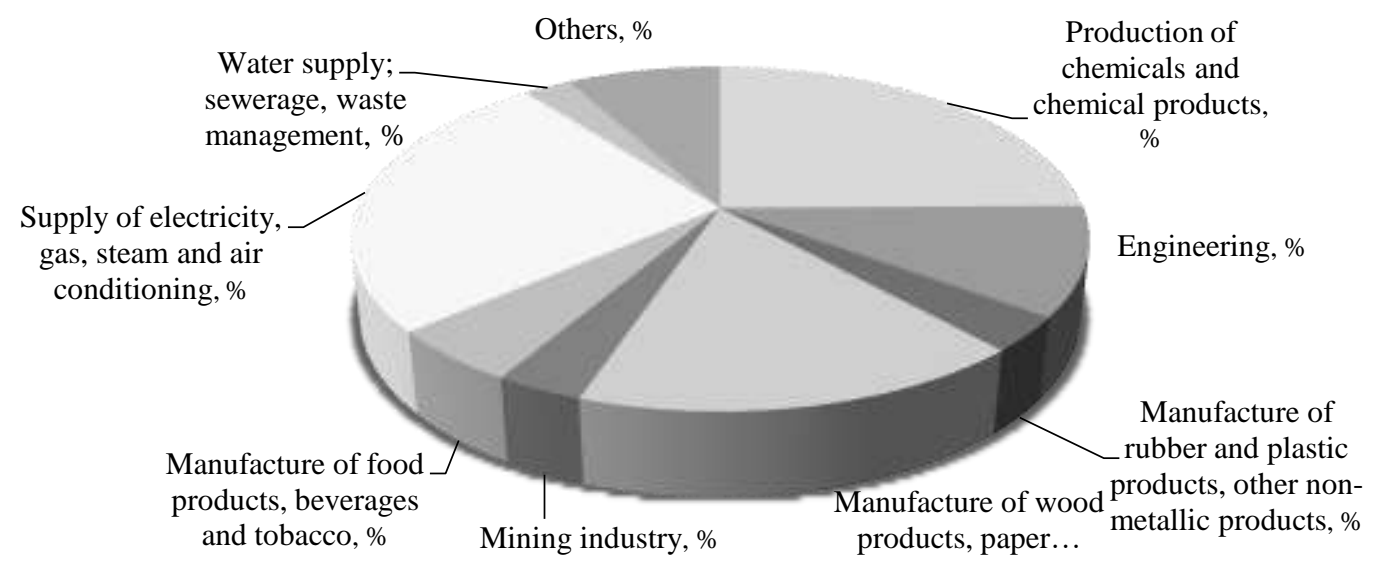

Figure 2. Structure of industrial sold products (goods, services) of Luhansk region in percentage to all sold products on the December 2020

(Main Department of Statistics in Luhansk region, 2020d)

The number of industrial enterprises on the December 2020 is 575 , of which: 85 are in the mining and quarrying industry, 365 are in the processing industry. They employ 30.3 thousand people (Luhansk Regional State Administration, 2020a).

The main industrial enterprises are concentrated in the cities of Sievierodonetsk, Rubizhne, and Lysychansk. Their share in the total volume of sold industrial products of the region is almost $50.0 \%$. The main enterprises are PJSC "Sievierodonetsk Association Azot ", SPE "Zorya" Ltd., VKF "TANA" Ltd. and others. The main enterprises of the machinebuilding industry operating on the territory controlled by the Ukrainian authorities: TDV "Popasne Car Repair Plant", PJSC "SNVO Impulse", SPE "Microterm" Ltd. (Luhansk

Copyright (C) 2021 Author(s), published by Vytautas Magnus University. This is an open access article distributed under the terms of the Creative Commons Attribution Non-Commercial 4.0 (CC BY-NC 4.0) license, which permits unrestricted use, distribution, and reproduction in any medium provided the original author and source are credited. The material cannot be used for commercial purposes. 
Regional State Administration, 2020a).

From the 40 industrial parks included in the Register of Industrial Parks of Ukraine, none have been recorded in Luhansk region. However, the Master Plans of Sievierodonetsk, Lysychansk, and Rubizhne define rather large industrial areas, and these cities have a large number of scientific and research institutions that can be involved in the creation of industrial parks and technology parks. Most land plots are located in areas that have a convenient geographical location, provided with engineering, and transport infrastructure.

Energy infrastructure. The main energy generating enterprises in the region are SE "Luhansk TPP", PJSC "DTEK Skhidenergo" and SOE "Sievierodonetsk CHP". The share of Luhansk region in Ukraine in electricity production is $3.7 \%$. The region accounts for $7.1 \%$ of the total natural gas consumption in Ukraine to produce it, however, these volumes are not enough to ensure the region's energy independence.

One of the main reasons for the decline of energy infrastructure in Luhansk region was Russia's armed aggression in Donbas. For many years, coal has been a reliable energy resource. However, since the beginning of the conflict, 55 mines have remained in the territory not controlled by the Ukrainian authorities. The shortage of coal has led to a lack of its reserves at thermal generation companies; in particular, Luhansk TPP is the only source of energy supply to consumers in the part of Luhansk region that controlled by Ukraine. Today, this part of Luhansk region is in the so-called "energy island" - all main power lines remain in the uncontrolled territory.

Strategic for the region is the issue of connection with the Unified Energy System of Ukraine, which will provide a reliable energy supply to social and industrial facilities; to launch powerful enterprises, in particular the Sievierodonetsk association "Azot", to attract investments to the territory of the region. Renewable energy facilities registered only in the temporarily occupied territory.

In addition to these problems, energy infrastructure characterized by an unbalanced structure of energy consumption and irrational use of energy resources (natural gas, electricity, heat) due to the use of outdated technologies with low efficiency and meters, or their absence.

\section{Conclusions}

Revealing and substantiating conceptual provisions of the infrastructural support for the post-conflict territories development allowed achieving the purpose of the article through the next steps. It has been analysed and justified the main types of infrastructure (industrial, housing and communal, social, transport, agricultural and energy) as that provide development of post-conflict areas; it helps to ensure key areas (social and economic) for further strategic development of the Luhansk region. The following analysis allowed detecting unsatisfactory results of the infrastructure subsystems in the region that felt the most stress and were the first to react to the negative impact of a combination of force majeure, namely housing and social and social, need special discussion.

It was identified some problematic hot spots in the state of the infrastructure that hinder the sustainable development of the Luhansk region. Thus, the general assessment of the economic and social components showed that the infrastructure of region is in an unsatisfactory condition, which cannot provide a sufficient pace of its development, especially sustainable. It is clear that to some extent this situation is due to the loss of much of it because of the temporary occupation of certain areas of the region and the destruction during shelling and hostilities during the armed aggression of the Russian Federation in eastern Ukraine. However, the restoration of infrastructure is quite slow, and its development takes place only point by point. In the conditions of unresolved conflict and insufficiency of own resources of local self-government bodies, despite the effectiveness of decentralization reform, the development of regional production and social infrastructure needs state support.

Besides, we suggest solution to the 


\section{Management Theory and Studies for Rural Business and Infrastructure Development}

eISSN 2345-0355. 2021. Vol. 43. No. 1: 67-76

Article DOI: https://doi.org/10.15544/mts.2021.06

abovementioned problems in terms of war conflict and COVID-19 pandemic by creating and implementing the provisions of the Concept of socio-economic development of post-conflict territories, especially in the Luhansk region. Within its framework, conceptual approaches to the socio-economic development of the Luhansk region propose for maximum concentration of efforts on the development of social infrastructure at the local level (villages, cities, territorial communities). Local communities should be the basis for development, which should develop infrastructure and create an attractive business environment that will ensure the sustainable development of communities.

Within it, the conceptual approaches to the socio-economic development of Luhansk region should include implementation of the Strategy, which extends to the territory controlled by Ukraine with the possibility of further scaling the economic system to the temporarily occupied territories after their reintegration to Ukraine. The authorities should take into account the requirements of Ukraine's international obligations, including the Association Agreement between Ukraine and the European Union, which ignores. Local areas in the Luhansk region (villages, cities, territorial communities) should be the basis for regional development, which should create attractive conditions for ensuring sustainable development. The ultimate goal of the Concept, and within its renewed strategies of regional and community development, will be the formation of advanced development of Luhansk region, which will ultimately provide comfortable living conditions, self-realization and development of citizens, improving their quality of life in post-conflict areas through infrastructure development.

\section{References}

Anand, P.B. (2005). Getting infrastructure priorities right in post-conflict reconstruction, in: WIDER Research Paper, 42, The United Nations University World Institute for Development Economics Research (UNU-WIDER), Helsinki.

Amr, S.H. (2013). Theories of Economic Integration: A Survey of the Economic and Political Literature, in: International Journal of Economy, Management and Social Sciences, 2(5), 9-17.

Budić, Z. (1994). Effectiveness of Geographic Information Systems in Local Planning, in: Journal of the American Planning Association, 60(2), 244-263. https://doi.org/10.1080/01944369408975579.

Albalate, D., Bel, G., \& Fageda, X. (2012). Beyond the efficiency-equity dilemma: Centralization as a determinant of government investment in infrastructure, in: Papers in regional science, 91(3), SI, 599-615. https://doi.org/10.1111/j.1435-5957.2011.00414.X

Lytvynchuk, I., Skydan, O., \& Ivaniuk, O. (2021). Local governance and territorial development on the basis of GIS, in: Management Theory and Studies for Rural Business and Infrastructure Development, 42(4), $422-433$. https://doi.org/10.15544/mts.2020.

Fageda, X., \& Olivieri, C. (2019). Transport infrastructure and regional convergence: A spatial panel data approach, in: Papers in regional science, 98(4), 1609-1631. https://doi.org/10.1111/pirs.12433.

Eyitope, O.A. (2020). The socio-economic drivers of public infrastructures development in Nigeria, in: International Journal of Critical Infrastructures, 16(4), 328-34. https://doi.org/10.1504/IJCIS.2020.112063

Chen, Zh., \& Haynes, K.E. (2018). Comparative assessment of public transportation infrastructure and regional economic development, In K. Matsushima, W. Anderson (Ed.), Transportation, knowledge and space in urban and $\begin{array}{llll}\text { regional } & \text { economics } & \text { Retrieved f7-98). }\end{array}$ https://www.elgaronline.com/view/edcoll/9781785366055/9781785366055.xml https://doi.org/10.4337/9781785366062.

Rohozian, Yu., Noskova S. (2017). Interregional cooperation as a prerequisite for the economic development of amalgamated territorial communities in Ukraine, in: Baltic Journal of Economic Studies, 3(5), 383-390.

Zablodska, I., Hrechana, S., Zablodska, D. (2020). The Identification of the Luhansk Region and the Region Act's

Copyright (C) 2021 Author(s), published by Vytautas Magnus University. This is an open access article distributed under the terms of the Creative Commons Attribution Non-Commercial 4.0 (CC BY-NC 4.0) license, which permits unrestricted use, distribution, and reproduction in any medium provided the original author and source are credited. The material cannot be used for commercial purposes. 
According to the Qualification of Their Sustainable Development in the Conditions of the Joint Forces Operation, in: Problemy Ekorozwoju, 15(1), p. 197-210.

Luhansk regional state administration (2020a). Information and analytical reference on the main trends of socioeconomic development of the region, http://loga.gov.ua/sites/default/files/collections/dodatok1_3.pdf (15.12.2020)

Luhansk regional state administration (2020b). Socio-economic analysis Luhansk region, http://loga.gov.ua/sites/default/files/collections/socialno-ekonomichniy_analiz_0.pdf (10.12.2020).

Main department of statistics in Luhansk region (2020a). About payment by the population of the Luhansk region of housing and communal services in October 2020, http://lg.ukrstat.gov.ua/expres/2020/graf_2020.php.htm (10.12.2020).

Main department of statistics in Luhansk region (2020b). Education, http://lg.ukrstat.gov.ua/sinf/osvita/osvita.php.htm (10.12.2020).

Main department of statistics in Luhansk region (2020c). Housing stock, http://lg.ukrstat.gov.ua/sinf/gilfond/gilfond0610_1.php.htm (10.12.2020).

Main department of statistics in Luhansk region (2020d). Volume of sold industrial products by types of activity in January-October 2020, http://lg.ukrstat.gov.ua/sinf/promis/promis10_2020.php.htm (10.12.2020). 